\title{
FUTEBOL, MÍDIA E SOCIEDADE: A ESPETACULARIZAÇÃO DA IMAGEM DO SUCESSO E SUAS INFLUENNCIAS ${ }^{1}$
}

\section{SOCCER, MEDIA AND SOCIETY: THE SPECTACULARIZATION OF THE IMAGE OF SUCCESS AND ITS INFLUENCES}

\author{
Gustavo Souza da Silva ${ }^{*}$ \\ Cristina Schmidt ${ }^{* *}$
}

\begin{abstract}
RESUMO
O futebol é o esporte mais popular do mundo. No Brasil, a modalidade não só tem grande apelo entre as massas como compõe a identidade nacional e cultural do povo, sendo capaz de provocar as mais variadas paixões, mobilizar diferentes classes sociais e influenciar, diretamente, o cotidiano, o comportamento e os sonhos dos amantes da bola. Por toda essa importância na sociedade e por sua capacidade de gerar audiência, o futebol, desde sua profissionalização nos anos 1930, tem sido altamente visado pelo jornalismo, pelo entretenimento midiático e pelo mercado publicitário. Diante disso, este artigo, por meio de levantamento bibliográfico e entrevista em grupo focal com 11 jogadores de base, objetiva compreender a espetacularização do esporte e atletas na mídia, bem como as suas influências junto a adolescentes que sonham com uma carreira profissional de sucesso no futebol.
\end{abstract}

Palavras-chave: Futebol. Espetacularização. Mídia.

\begin{abstract}
Soccer is the most popular sport in the world. In Brazil, the game not only has great appeal among the masses as the national and cultural identity of the people, being able to cause various passions, mobilize different social classes and influence, directly, the everyday, the behavior and the lovers 'dreams of the ball. For all the importance in society and by your ability to generate audience, soccer, since your professionalism in the years 1930, has been strongly endorsed by the journalism, by media and entertainment by the advertising market. Given this, this article, through bibliographical survey and focus group interview with 11 players, aims to understand the spectacularization of the sport and athletes in the media, as well as their influences with the teenagers who dream of a professional career of success in football.
\end{abstract}

Keywords: Soccer. Spectacularization. Media.

\footnotetext{
${ }^{1}$ Os resultados deste estudo são decorrentes de duas edições do Programa Institucional de Bolsas de Iniciação Científica (Pibic), de apresentações nos congressos nacionais da Intercom Júnior 2016 e 2017 e do Trabalho de Conclusão de Curso (TCC) vinculado à graduação em Comunicação Social com Habilitação em Jornalismo e ao Núcleo de Ciências Sociais Aplicadas, na Universidade de Mogi das Cruzes.

"Mestrando em Políticas Públicas e bacharel em Comunicação Social com Habilitação em Jornalismo pela Universidade de Mogi das Cruzes-SP (UMC). Realiza pesquisa na área de Teorias da Comunicação, com análise de produtos jornalísticos, estudos de recepção midiática, políticas de comunicação, comunicação pública, participação popular, cidadania e relações entre Estado, mídia e sociedade. É jornalista, pesquisador, assessor de imprensa e redator.

"*ós-doutora pela Cátedra UNESCO/Umesp. Doutora em comunicação e Semiótica pela PUC-SP; Mestre em Teoria e Ensino em Comunicação pela MetodistaSP, Atualmente é professora e pesquisadora do Mestrado em Políticas Públicas da Universidade de Mogi das Cruzes- UMC. Coordena o Grupo de Pesquisa Comunicação, Diversidade e Cidadania CNPq/UMC. Também atua no Curso de Comunicação da UMC, e nos Cursos de Direito e Pedagogia na Faculdade Bertioga - FABE. É Sócio-fundadora da Rede Folkcom, Sócia da Intercom, e Diretora Administrativa da SOCICOM.
} 


\section{INTRODUÇÃO}

Este artigo tem o propósito de compreender a lógica da espetacularização do futebol e dos atletas mais destacados na mídia, analisando de que modo a imagem de sucesso vinculada ao esporte e difundida massivamente pelas milhões de telas influencia adolescentes brasileiros que sonham ter uma vida melhor por meio da carreira de jogador profissional, ou seja, jovens que enxergam na modalidade uma via de acesso ao estrelato, à riqueza e à fama, apesar de a realidade futebolística se apresentar muito mais complexa e menos glamorosa do que aquela difundida pela imprensa.

A relação entre meios de comunicação e futebol, aliás, vai muito além da cobertura jornalística de grandes eventos esportivos e da difusão massiva de informações a respeito dos torneios e clubes. Ela implica uma dinâmica que consiste em conquistar, prender e encantar a audiência, transformando partidas em verdadeiros espetáculos de imagens, e jogadores profissionais em ídolos, heróis e celebridades (BARBEIRO e RANGEL, 2006; BIANCO e RODRIGUES, 2012; COELHO, 2006; GASTALDO, 2009).

Configurado sob a lógica dos esportes modernos que, vinculados à imprensa, precisam construir seus astros para serem consumidos avidamente pelo público, o futebol torna-se um espetáculo e uma mercadoria com um fim puramente comercial, cuja dinâmica envolve a busca constante por lucros a partir de um processo de alta produção e consumo (PRONI, 1998).

Nessa perspectiva, é possível dizer que o futebol chega à nossa época como um produto da indústria cultural e, como tal, necessita, além da audiência, de jovens dispostos a apostar alto na carreira futebolística, de forma que seja sistematicamente renovado o plantel de astros e de aspirantes ao estrelato.

A questão, porém, é que o acesso a um patamar de sucesso no esporte é uma condição difícil de se alcançar. Ela é restrita a alguns poucos jogadores com capacidade técnica e habilidade diferenciadas, além de personalidade marcante e de empresários influentes no mercado da bola (BENINI, 2012).

É fato, também, que a exibição e o enquadramento espetaculares do futebol na mídia não refletem, fielmente, a realidade do esporte no país. A cobertura massiva dos clubes da elite e dos atletas mais destacados acaba por ocultar a existência de tamanha desigualdade financeira entre os times e os jogadores espalhados pelo Brasil (BENINI, 2012).

De acordo com dados da Confederação Brasileira de Futebol (CBF), referentes a $2015^{2}$, de 28.203 atletas ligados por contrato definitivo aos 776 clubes profissionais cadastrados na entidade, $82,4 \%$ - mais de 23.200 atletas - ganhavam mensalmente até R \$ 1.000,00 de salário; apenas 0,28\% - 78 atletas - recebiam entre R\$100.000,00 e R\$200.000,00; e $0,12 \%-35$ atletas - embolsavam entre $\mathrm{R} \$ 200.000,00$ e R $\$ 500.000,00$ mensais. Ou seja, menos de 1\% dos jogadores profissionais no Brasil recebiam salários acima de cem mil reais.

Diante desse panorama, este artigo levanta algumas problematizações teóricas, como: por que, apesar desses números, uma massa de jovens brasileiros ainda sonha com uma carreira futebolística de sucesso e busca na modalidade a obtenção de dinheiro e fama, deixando a família, a adolescência e, em muitos casos, até mesmo os estudos para se dedicar ao esporte? De que maneira a história (contada na mídia) de uma minoria de atletas que saiu da pobreza e, por meio do futebol, alcançou o estrelato é capaz de influenciar tantos outros a desejarem uma conquista semelhante? A família, o contexto socioeconômico e a cultura da mídia contribuem significativamente para a construção desse sonho, ou somente o forte traço histórico do futebol como paixão, cultura e identidade nacional já seriam fatores suficientes para explicar tal questão?

Segundo Magalhães (2010), o estudo histórico do futebol permite uma compreensão aprofundada e peculiar sobre a construção da sociedade brasileira, em virtude da tamanha importância que o esporte ganhou no país a partir do século XX, constituindose como um "elemento fundamental" da identidade e cultura do povo.

Tal fato concede ao futebol o status de paixão nacional, além de uma cobertura de destaque na mídia, enquanto um reluzente espetáculo de massa (GASTALDO e HELAL, 2013). A motivação deste estudo, portanto, surgiu da reflexão sobre a discrepância na cobertura jornalística do universo

\footnotetext{
${ }^{2}$ Os números fazem parte de um relatório inédito da Diretoria de Registro e Transferência (DRT) da CBF. A iniciativa teve como objetivo dar transparência à realidade do futebol, mas não foi repetida nos anos posteriores.
} 
futebolístico, que delimita seu olhar exclusivamente para uma minoria de clubes e atletas pertencente à elite do esporte, desconsiderando a maior parte dos demais expoentes, que possui ínfimos recursos financeiros e que enfrenta enorme dificuldade para se manter nos campeonatos oficiais.

Sobre isso, Bianco e Rodrigues (2012) explicam que os programas esportivos de televisão comercial, por exemplo, adotam a espetacularização - ou seja, transformar atletas em celebridades - como estratégia mercadológica para conquistar audiência.

Para as autoras, essa perspectiva implica selecionar certos tipos de conteúdo, abordagens e narrativas, descartando outros temas que não "interessam" ao público e, logo, não rendem audiência, a exemplo de pautas como as péssimas condições em que trabalham os jogadores dos "pequenos" clubes, muitas vezes submetidos a contratos abusivos, curtos e com salários irrisórios.

Dessa forma, a comunicação midiática tende a criar no imaginário coletivo a ideia de que o futebol se resume a um mundo de encantos e de oportunidades, no qual uma pequena parcela de jogadores alçados à condição de mitos representa o sonho de milhares de brasileiros que certamente gostariam de ganhar muito dinheiro e fama jogando futebol (BENINI, 2012).

A intenção deste artigo, afinal, é suscitar uma discussão crítica acerca da realidade do futebol brasileiro e do discurso do jornalismo esportivo na cobertura futebolística, entendendo que a imprensa esportiva precisa construir e explorar as imagens dos ícones do esporte, na medida em que está inserida no contexto da cultura da mídia e da indústria do entretenimento.

Logo, partindo da hipótese inicial de que a comunicação midiática influencia jovens a sonharem com uma carreira futebolística de sucesso, e que essa condição é restrita a alguns poucos jogadores selecionados a partir de critérios que extrapolam as atuações no campo de jogo, este artigo também busca preencher uma lacuna informacional e interpretativa deixada pela cobertura jornalística tradicional. Não obstante, essa problemática tem sido, ao que parece, pouco abordada e investigada por estudos interdisciplinares nas áreas de comunicação e ciências sociais.

Para tanto, este artigo caracteriza-se como exploratório, de natureza qualitativa, realiza levantamento bibliográfico com foco nos conceitos de indústria cultural e sociedade do espetáculo, além de uma entrevista em grupo com 11 jogadores de base vinculados a um clube profissional da região metropolitana de São Paulo.

Além desta introdução e das considerações finais, o texto está dividido em quatro partes. $\mathrm{Na}$ primeira, contextualiza-se a posição e importância do futebol na sociedade brasileira, enquanto elemento de identidade nacional e meio de vida. A segunda aborda o jornalismo esportivo e o futebol como produtos midiáticos da Indústria Cultural. Já a terceira expõe uma discussão em torno do conceito de Sociedade do Espetáculo e os padrões das sociedades contemporâneas guiadas por consumo e imagens. Por fim, na quarta parte, são expostos e discutidos os dados qualitativos da entrevista em grupo com jovens atletas, com vistas a identificar e entender algumas variáveis relacionadas à influência da espetacularização midiática do esporte sobre seus sonhos.

\section{FUTEBOL COMO IDENTIDADE NACIONAL E MEIO DE VIDA}

É possível levantar diversas hipóteses sobre fatores que podem influenciar consideravelmente um jovem brasileiro a sonhar com a carreira de jogador de futebol. Essa influência certamente converge com a história do esporte no Brasil, principalmente no que se refere à paixão e à identificação do povo brasileiro com a modalidade, bem como com a forma que o futebol é tratado e difundido pelos meios de comunicação, como já dito, segundo uma lógica mercadológica que privilegia a espetacularização de partidas e de atletas, transformando-os, respectivamente, em espetáculos e personagens midiáticos, ricos, adornados e exemplos de vitória, de meritocracia e superação.

Ora, pode-se considerar ainda outras questões mais subjetivas que envolvem, por exemplo, a situação socioeconômica e familiar dos jovens aspirantes a jogadores profissionais, ou, mais especificamente, o desejo de transformar essa condição por meio do estrelato futebolístico.

A princípio, o que se propõe neste tópico é compreender, brevemente, a construção histórica do futebol enquanto paixão e identidade do povo brasileiro e, a partir desse enfoque, discutir como o 
esporte tornou-se uma via de acesso à ascensão social e um meio de vida para muitos futebolistas.

A verdade é que, como se verá a seguir, de um jogo lúdico pertencente às elites, o futebol passou a ser um esporte de massa, popular em todas as classes sociais e altamente rentável para vários setores econômicos, inclusive para atletas, meios de comunicação, empresas, marcas, confederações nacionais e internacionais, empresários e clubes de destaque (RIBEIRO JÚNIOR et al., 2014; SOMOGGI, 2016). Com isso, o esporte está inserido em um mercado milionário que movimenta valores exorbitantes no mundo inteiro, com vendas e compras de jogadores, direitos de transmissão televisiva, publicidade, comercialização de materiais esportivos, bilheteria, entre outros.

Desde que chegou ao Brasil, no final do século XIX, junto com as bagagens de Charles Miller, o futebol tem acompanhado todas as transformações sociais, tecnológicas e políticas pelas quais passou o país no decorrer do tempo. Nesse sentido, Magalhães (2010, p. 9) é pontual ao dizer que o esporte é um elemento importante para a compreensão da sociedade e cultura do povo brasileiro. Para a historiadora, "estudar o futebol a partir de uma perspectiva histórica é conhecer mais da nossa sociedade, dos costumes e da nossa própria história".

$\mathrm{Na}$ época em que o futebol moderno foi importado da Inglaterra para a cidade de São Paulo - até então economicamente emergente devido à alta produção e exportação de café -, a sociedade brasileira ainda não tinha uma identidade coletiva, isto é, um senso de nação e pertencimento ao território. Fazia pouco tempo que o país havia "abolido" a escravidão e deixado a monarquia para proclamar a República. No campo da infraestrutura e da economia, a intenção era colocar as capitais do sudeste brasileiro nos moldes das grandes metrópoles europeias. Para isso, o processo de industrialização era imprescindível e, com ele, formavam-se novas estruturas sociais no ambiente urbano, a partir da imigração massiva de famílias do Velho Continente e da divisão de classes (MAGALHÃES, 2010; PRONI, 1998; WITTER, 1996).

Segundo relatam historiadores como Witter (1996), o futebol inicialmente era uma atividade restrita ao lazer burguês, em função do alto investimento que se precisava lançar mão para adquirir os materiais de jogo, todos importados do exterior. Os registros, de acordo com o autor, dão conta de que o futebol era praticado somente por filhos de famílias com posses, que formavam a elite da época. Dessa forma, as questões financeiras afastavam o acesso ao esporte dos mais pobres, em razão da necessidade de recursos para comprar as chuteiras, a bola e os uniformes que custavam caro.

Magalhães (2010) descreve que o objetivo das elites era manter o futebol distante das classes populares e, principalmente, dos negros. No entanto, como se sabe, a proposta não durou por muito tempo. A expansão industrial e o crescimento do operariado contribuíram consideravelmente para que o esporte fosse democratizado entre os trabalhadores, visto que muitas fábricas passaram a criar seus próprios times para disputar campeonatos, realizar excursões e, por meio desses eventos, divulgar suas marcas.

Muitas empresas, inclusive, pagavam para os operários jogarem. Algumas delas deram origem a clubes que até hoje permanecem ativos, como é o caso do carioca The Bangu Atletic Club, fundado por trabalhadores ingleses da Companhia Progresso Industrial, e o Sport Club Corinthians Paulista, criado também por iniciativa de operários, a maioria imigrantes, que trabalhavam em ferrovias inglesas no bairro do Bom Retiro, em São Paulo (MAGALHÃES, 2010). Tais práticas, afinal, amadureceram a ideia de profissionalizar o esporte, de torná-lo um negócio lucrativo, um meio de vida e uma possibilidade de ascensão social.

Curiosamente, ao contrário dos propósitos iniciais, a popularização do futebol no Brasil teve relação próxima com a intenção da aristocracia econômica de manter o controle sobre as massas populares, submetidas a péssimas condições de vida, marcada por intenso esforço físico nas relações de trabalho, e em estado psicológico vulnerável decorrente de privações, falta de direitos e identidade.

Os trabalhadores encontravam no futebol uma espécie de "válvula de escape", bem como uma maneira de subverter a estrutura econômica e social fundamentada em uma desigualdade profunda e complexa. Se, inicialmente, o intuito era restringir o esporte às elites do país, com os conflitos políticos e sociais que emergiam de forma acentuada nos centros urbanos, o futebol passou a ser utilizado como uma estratégia de aliviar tensões, semelhantemente com 
o que ocorrera na Inglaterra (MAGALHÃES, 2010; WITTER, 1996).

Foi nesse contexto que o futebol ganhou espaço e se consolidou junto às massas. Com o tempo, as Copas do Mundo foram incorporadas à cultura do brasileiro e se tornaram fatores fundamentais para a formação do sentimento coletivo de nação no país durante os jogos da seleção canarinho. Por meio do futebol, aliás, o Brasil passou a ser visto de modo diferente pelos demais países, conforme ia ganhando características de Estado-nação (MAGALHÃES, 2010; WITTER, 1996).

Tal panorama pôde ser visto na Copa de 1950, sediada no Brasil pela primeira vez. Os governantes, à época, viam no evento uma oportunidade única de mostrar ao mundo as particularidades do país, suas belezas naturais e a diversidade do povo. Magalhães (2010, p. 86) pontua que o evento também "era uma forma de despertar um sentimento de coletividade, já que ainda se lutava pela integração nacional". A historiadora retrata a percepção do povo durante o torneio global:

A emoção às vésperas da final era impressionante. Para uma população majoritariamente das classes mais baixas, ver jogadores de origem comum à sua dando um verdadeiro espetáculo era quase uma vingança pela constante exploração do sistema excludente e elitista em que vivia. (MAGALHÃES, 2010, p. 88).

Nota-se que, ainda hoje, o futebol constitui um elemento de identidade e integração nacional. Para as classes populares em especial, significou uma das primeiras formas de manifestação cultural e de entretenimento, assim como um caminho para os mais pobres encontrarem uma identidade e fazerem parte de uma comunidade (MAGALHÃES, 2010).

O processo de democratização e popularização do futebol, porém, motivou algumas tensões políticas no país, a exemplo dos embates entre os que defendiam o amadorismo do esporte e os que eram a favor da profissionalização. O primeiro argumento pertencia a uma parte da elite, interessada em preservar o futebol como lazer. Já o segundo era buscado pelas classes mais pobres, principalmente operários de fábricas que queriam fazer do futebol uma profissão, além daqueles que enxergavam o esporte para além de uma simples atividade física. Esses viam a modalidade como uma oportunidade de negócio, tendo em vista o exponencial crescimento das torcidas e do apelo social e midiático do esporte (MAGALHÃES, 2010; PRONI, 1998).

Nesse sentido, Fernández (1974) considera que o futebol, antes de um meio de vida, é ao mesmo tempo uma paixão nacional e um fenômeno social e linguístico. Para essa autora, o esporte tem um forte apelo entre as classes menos prestigiadas no ambiente urbano, por ser um jogo simples de ser praticado e pelas semelhanças e o paralelo que tem em relação à vida do homem em sociedade.

As proposições da professora têm fundamento nos estudos de Johan Huizinga (2005) que, a partir de uma perspectiva histórica, compreende o "jogo" como um elemento da cultura humana, que transcende os fenômenos físicos e biológicos, sendo um significante das ações dos homens. Para o autor holandês, a noção de jogo como elemento cultural se estende à linguagem, à competição como função cultural e social, como divertimento e, ao mesmo tempo, competição (GASTALDO e HELAL, 2013). Enfim, a noção de jogo está presente em tudo o que acontece no mundo e nas relações sociais em geral.

Dessa maneira, Fernández (1974) entende que o esporte está estritamente vinculado ao conceito de exercícios físicos no âmbito de um jogo cujo objetivo é buscar algo ou alguma representação por meio da disputa. No futebol, afinal, ora o indivíduo e o grupo conquistam a vitória, ora deparam-se com a derrota. Nesse contexto, os expoentes da modalidade também são submetidos a regras, estão sujeitos a sentimentos como frustração, alegria, inferioridade ou supremacia na competição. Além de situações que provocam adrenalina, raiva, desafios, medo e indignação, assim como ocorre na vida diária.

A autora considera que as transformações pelas quais passou o futebol ao longo da história, deixando o amadorismo (futebol-esporte) para se tornar profissional (futebol-meio de vida), levaram o jogo de bola a deixar de ser um fim em si mesmo, ou seja, a perder seu aspecto lúdico. Segundo Fernandéz (1974, p. 22), "dentro dos padrões de produção e consumo, o futebol acabou por se configurar como atividade comercial com fins lucrativos", como "um fenômeno financeiro e sério".

Magalhães (2010) compreende que a passagem do futebol lúdico para o profissional tem relação estreita com a popularidade e representatividade que 
o esporte ganhou por meio dos clubes. Essa nova realidade gerou algumas consequências, como o crescimento das torcidas, e com ele o aumento da exigência por resultados expressivos e conquistas.

Segundo a historiadora, a profissionalização do futebol não foi um fato isolado, mas sim um processo correlacionado com o contexto social e político do Brasil da década de 1930. Depois da República Velha, Getúlio Vargas assumiu a presidência e foi exatamente em seu longo mandato, a maior parte sob regime ditatorial, que a classe operária começou a vislumbrar a conquista de direitos trabalhistas. Apesar dessa contextualização, a profissionalização do esporte foi efetivada uma década antes da Consolidação das Leis do Trabalho (CLT), criada em 1943 (MAGALHÃES, 2010).

O novo cenário do futebol nacional, marcado pelo profissionalismo e a elevação do nível de competitividade, contava de uma vez por todas com uma configuração bem diferente da inicial, como sublinha Witter:

[...] Essas duas histórias são emblemáticas de um período em que as mudanças mais significativas na composição social dos quadros (assim eram denominadas as equipes) dos diferentes times. Que mudanças? Principalmente a substituição dos rapazes ricos pelos operários das fábricas e pelos negros, que começam a aparecer no cenário futebolístico (WITTER, 1996, p. 16).

O Club de Regatas Vasco da Gama, do Rio de Janeiro, foi um dos primeiros times brasileiros a contratar jogadores pobres e negros. Em 1923, em sua estreia na elite do Campeonato Carioca, a equipe cruzmaltina faturou o título do torneio e incomodou profundamente as elites, responsáveis por maior parte das agremiações que figuravam na competição até então (MAGALHÃES, 2010).

Com uma preparação mais profissionalizada que a dos adversários, o Vasco não somente venceu o torneio como abriu caminho para a profissionalização do esporte no Rio de Janeiro, capital federal na época. Tal fato levou os demais clubes a adotarem a mesma metodologia e estrutura de gestão das entidades

Vale ressaltar também que, nessa época, era bastante vantajoso para os operários jogarem futebol pelos times das fábricas nas quais estavam empregados. Isso porque, como sintetiza Magalhães (2010), além de receberem dinheiro e premiações pelas vitórias, trabalhavam menos e tinham mais chances de serem promovidos. Nasce dessas práticas, portanto, a imagem do futebol como um caminho que permitia obter melhores condições de vida e ascensão social.

Magalhães (2010, p. 119) explica que, depois da passagem do amadorismo para o profissionalismo, o futebol brasileiro e mundial entrou em uma nova fase a partir dos anos 1980, a "era do marketing e de seu capital", acompanhando inúmeras transformações em todo o mundo, como o Fim da Guerra Fria, a queda do muro de Berlim e a expansão da globalização e do neoliberalismo nas políticas econômicas e nas relações internacionais do Ocidente.

Tais mudanças, segundo a historiadora, culminaram no processo desestatização, iniciado na Europa, o qual tirou o poder absoluto das emissoras de televisão estatais, gerando grandes concorrências entre as empresas privadas de comunicação pelos direitos de transmissão dos jogos. O resultado foi o aumento exponencial de dinheiro recebido pelos clubes e federações que, com o interesse de valorizar as competições e atrair mais lucros, passaram a investir pesado em contratações de futebolistas do mundo inteiro, sobretudo os sul-americanos.

O futebol brasileiro também sentiu reflexos importantes dessas transformações. Com efeito, o êxodo de jogadores brasileiros para o exterior, situação cada vez mais frequente pelas altas propostas dos clubes europeus, potencializava a visão do futebol como meio de vida, ascensão e estrelato. $\mathrm{Na}$ realidade, uma vez envolvidos em transações como essas, os jogadores tinham a oportunidade peculiar de ganhar muito mais dinheiro e de ser reconhecidos internacionalmente como astros da bola (PRONI, 1998; RIAL, 2008).

$\mathrm{Na}$ era do marketing, portanto, como bem pontua Magalhães (2010, p. 120), o capital gerado por meio de patrocínios, publicidade e investimentos de emissoras de televisão no futebol "passava a ser o definidor das relações do esporte". Nessa perspectiva, o jogador também passou a ter condição e características de produto, ao passo que os clubes brasileiros, abitolados de problemas financeiros, enxergavam (e ainda enxergam) na venda de seus talentos uma forma de aliviar o caixa e gerar novos recursos (PRONI, 1998).

A mesma situação se tornou objeto de desejo dos atletas (principalmente seus empresários), que 
não mais se contentam em realizar o sonho de jogar profissionalmente pelos grandes times do futebol brasileiro. Agora, o desejo consiste também em brilhar com as camisas de equipes europeias e se transformar em um ícone global.

\section{INDÚSTRIA CULTURAL: O JORNALISMO E O FUTEBOL COMO PRODUTOS}

Com base na abordagem de Fernández (1974), nota-se que a paixão e identificação despertadas pelo futebol no povo brasileiro motivaram um grande interesse dos meios de comunicação em produzir conteúdos relacionados ao esporte. Tal cenário, porém, nem sempre foi assim, tendo em vista que o jornalismo esportivo não tinha tanto espaço nas páginas dos jornais no início da peregrinação do futebol pelo Brasil.

Coelho (2006) observa que o remo era a principal modalidade esportiva em meados da década de 1910, sendo a única a ter matérias publicadas na imprensa da época. Com o passar do tempo, contudo, à medida que o futebol se consolidava e se expandia conforme o crescimento do número de clubes profissionais, de campeonatos e de torcidas, a mídia passava a conceder significativa atenção ao esporte, enxergando nele um potencial efetivo de ganhar audiência e fazer negócio.

Portanto, a popularização do futebol o conectou com a maior parte do segmento midiático brasileiro e o levou a ganhar destaque nos cadernos de suplementos esportivos dos grandes jornais, nas revistas especializadas, nos programas e transmissões de jogos no rádio e, a partir de 1950, também na televisão. Fernández (1974) destaca que o futebol, nessa perspectiva, deixou de ser um jogo recreativo para se tornar sério, ao passo que foi adotando características de esporte moderno, no contexto dos padrões estabelecidos pela imprensa.

Nesse sentido, Sodré (1984, p. 136) chama a atenção para a semelhança entre o futebol e a indústria, uma vez que, vinculado à mídia, o esporte necessita produzir personagens para vender suas imagens. Para o sociólogo, o futebol é "filho legítimo da Revolução Industrial”, razão pela qual "não se pode confundi-lo com o jogo físico, que se caracteriza pela espontaneidade de movimentos, pela despreocupação com relação a um fim produtivo, pela liberdade do corpo".

Dessa forma, é possível considerar que o futebol, nos padrões atuais da era do marketing, segue a linha de produção industrial, enquanto objeto de relações empresariais. Haja vista as suas regras e regulamentos, contratos econômicos, transações comerciais entre os mercados continentais, disciplina e repetição sistemática nos movimentos físicos dos atletas e nas estratégias táticas do jogo, evidenciando seu aspecto competitivo, da mesma forma como ocorre nas empresas.

A exigência excessiva de dirigentes (chefes) e torcedores (clientes) sobre os jogadores e treinadores (produtos), para que desempenhem em alto nível e apresentem resultados expressos em conquistas, fortalece a proposição de Sodré (1984, p. 140) de que "o futebol, mais do que mero esporte, tende hoje a transformar-se num grande espetáculo de massa".

Essa tendência é tão forte que até os nomes de clubes e estádios estão sendo substituídos por nomes de empresas, que pagam vultosas quantias em dinheiro para associarem suas marcas ao futebol. Os chamados "clubes-empresas", cada vez mais presentes no mercado da bola, funcionam como fábricas de jogadores de alto nível técnico e físico, produzidos e preparados para brilharem nos gramados, encherem os estádios e renderem milhões de euros.

Em discussão relacionada à espetacularização, Pena (2008, p. 88) afirma que, nos padrões da indústria do entretenimento, "a mídia produz celebridades para poder realimentar-se delas a cada instante em um movimento cíclico e ininterrupto". Segundo o autor, os eventos associados a um determinado personagem são capazes de ganhar dimensões inimagináveis de supervalorização, dependendo da "capacidade desse indivíduo em roubar a cena, ou seja, em tornar-se uma celebridade".

Para Pena (2008, p. 88-89), "as celebridades tornaram-se o polo de identificação do consumidorator-espectador do espetáculo contemporâneo. São eles que catalisam e preenchem o imaginário coletivo".

Logo, com a espetacularização de jogos e atletas, a indústria da mídia e do futebol passa a dispor de uma mercadoria altamente rentável e que lhe permite obter muito lucro com publicidade e propaganda. Com efeito, essa é a lógica que une 
futebol e mídia e os insere no circuito dos grandes negócios contemporâneos.

Dito isto, pode-se considerar que a mídia é responsável pela produção e difusão das imagens espetaculares de futebolistas que atingiram a condição restrita de craques, ídolos e símbolos de sucesso. Os meios de comunicação, motivados por seus interesses, utilizam diferentes estratégias comunicativas para transformar o jogo futebolístico em um verdadeiro espetáculo midiático, e os atletas em celebridades, conforme pontuam Bianco e Rodrigues (2012).

As autoras argumentam que os programas esportivos da mídia comercial adotam a espetacularização do esporte como estratégia de conquistar e prender a audiência. Espetacularizar, segundo elas, significa "transformar atletas em celebridades, em ícones da cultura da mídia ou reencarnar na narrativa da transmissão de eventos os mais profundos valores da sociedade como competição, sucesso e dinheiro" (BIANCO e RODRIGUES, 2012, p. 264).

De fato, o interesse da imprensa pelo futebol tem como fulcro atrair olhares, encantar (tel) espectadores e fomentar ainda mais a paixão pelo esporte para, desse modo, faturar contratos milionários junto ao mercado publicitário. Com essa perspectiva, Fernández (1974) compreende que a mídia atua de maneira efetiva no processo de pré-fabricação de heróis e mitos do esporte, e que, além de criar os ídolos, lapida suas imagens com esmero que extrapola o campo da notícia, visando tão somente ao potencial publicitário do esporte e dos atletas.

Kellner (2004, p. 2), por sua vez, salienta que "a celebridade também é produzida e manipulada no mundo do espetáculo". Para ele, "as celebridades são ícones da cultura da mídia, os deuses e deusas da vida cotidiana". Nesse sentido, os jogadores transformados em astros do espetáculo midiático-futebolístico tornam-se também exemplos de ascensão social e seu apelo junto ao público parece ser mais forte na medida em que percorrem trajetórias da pobreza e do anonimato à fortuna e à aclamação unanime na imprensa, nos estádios e nos espaços públicos.

Essa dinâmica midiática e espetacular tem relação com as características e funcionamento das sociedades contemporâneas, ditadas pelo alto capitalismo e consumo, nas quais o jornalismo se legitima segundo padrões industriais inerentes aos processos massificados de produção e distribuição da notícia, sua principal matéria-prima. Pena (2008, p. 90) diz que, nessa engrenagem, "a notícia é um produto à venda e está exposta na vitrine do capitalismo industrial" aos cidadãos/consumidores dos conteúdos produzidos e divulgados pela mídia que, na era do espetáculo e na lógica comercial, "fabrica ícones e veicula situações inusitadas ou irreverentes [...]", ou seja, produzem e difundem "entretenimento e espetáculo".

Com isso, é válido pressupor que o jornalismo, assim como a maior parte das atividades econômicas inseridas no contexto do alto capitalismo, tornouse um produto à venda, que necessita de consumo massivo para render dinheiro e sustentar sua indústria. Marcondes Filho (1989, p. 13), a esse respeito, enfatiza que a notícia nada mais é do que "a informação transformada em mercadoria com todos os seus apelos estéticos, emocionais e sensacionais".

Recorrendo aos estudos de Marx, o autor interpreta que as notícias não são apenas produtos, mas também "a forma elementar da riqueza no capitalismo; são mercadorias: o valor de uso e o valor de troca" (MARCONDES FILHO, 1989, p. 31). Essas concepções sobre o conceito de notícia no mundo capitalista ganham ainda mais ênfase quando são associadas à atuação do jornalismo esportivo na cobertura do futebol feita pela mídia tradicional.

Nessa perspectiva, é possível considerar que os limites entre jornalismo, entretenimento e sensacionalismo na cobertura futebolística se misturam quase sempre, ao passo que o esporte, apesar de ser um meio de vida para muitos e paixão para outros, representa lazer e diversão para a maioria. Por isso, não é incomum encontrar mais liberdade no uso da linguagem nesse tipo de conteúdo e abordagens voltadas para a fofoca, intrigas e ostentação de bens dos atletas ricos, o que não ocorre comumente em outros segmentos do jornalismo, como o político e o econômico.

Em tese, o objetivo desse formato de comunicação midiática é fazer com que o produto seja mais atraente ao público e, por conseguinte, mais consumido, pois, quanto maior for a audiência, maior também é o potencial publicitário. Inseridos nesse contexto, o futebol, enquanto objeto do processo de espetacularização para a conquista de audiência, e os jogadores, tratados como celebridades do 
espetáculo midiático-esportivo, são respectivamente transformados em produtos, ou melhor, em mercadorias.

Com essa lógica de mercado, pode-se dizer que o futebol e o jornalismo são produtos da indústria cultural. Apresentado pela primeira vez na década de 1940 pelos filósofos alemães Theodor Adorno e Max Horkheimer, expoentes da Escola de Frankfurt, o conceito de Indústria Cultural diz respeito ao processo padronizado de produção e comercialização de produtos culturais facilmente assimiláveis e voltados para o consumo em série.

Tal dinâmica ganhou força a partir do Iluminismo e da Revolução Industrial que culminaram no enfraquecimento da religião e dos modelos précapitalistas nas relações políticas, sociais, econômicas e culturais dos países do Ocidente. Nesse sentido, novas estruturas e sistemas passaram a compor as formas de monopólio econômico e social no contexto das sociedades industriais, a saber: a cultura de massa.

Adorno e Horkheimer (1985, p. 99) entendem que, "sob o poder do monopólio, toda cultura de massas é idêntica, e seu esqueleto, a ossatura conceitual fabricada por aquele, começa a se delinear". Para os pensadores alemães, nessa estrutura, os responsáveis pelo monopólio não têm mais o objetivo de camuflar seus reais interesses. Pelo contrário, essas formas de poder, isto é, os negócios como ideologia, afirmamse na medida em que são explícitas ao público, assim como ocorre com os meios de comunicação e entretenimento. Os filósofos afirmam:

$\mathrm{O}$ cinema e o rádio não precisam mais se apresentar como arte. A verdade de que não passam de um negócio, eles a utilizam como uma ideologia destinada a legitimar o lixo que propositalmente produzem. Eles se definem a si mesmos como indústrias, e as cifras publicadas dos rendimentos de seus diretores gerais suprimem toda dúvida quanto à necessidade social de seus produtos (ADORNO e HORKHEIMER, 1985, p. 99).

Teixeira Coelho (2006, p. 10-11) explica que a indústria cultural, assim como os meios de comunicação e a cultura de massa, surgiu do fenômeno da industrialização, cujas características refletemse no funcionamento das sociedades guiadas pelos padrões impostos pelo capitalismo. Nesse modelo de sociedade, o autor salienta a reificação (transformação em coisa ou "coisificação") e a alienação como fatores essenciais que tendem a homogeneizar e padronizar os hábitos de consumo cultural. "Para essa sociedade, o padrão maior de avaliação tende a ser coisa, o bem, o produto; tudo é julgado como coisa, portanto tudo se transforma em coisa - inclusive o homem".

Dessa maneira, argumenta o autor, a cultura passa a ser produzida em série, destinada a um número massivo de pessoas, sendo projetada não como "instrumento de livre expressão", nem de crítica e conhecimento, mas sim como mercadoria comercializada por dinheiro e feita para ser consumida como se consome qualquer outra coisa (TEIXEIRA COELHO, 2006, p. 23).

Para Adorno e Horkheimer (1985, p. 104), a indústria cultural, com toda sua complexidade, promove uma socialização das consciências que resulta em alienação das massas, na medida em que estas se tornam incapazes de refletir sobre a realidade e sobre si mesma. "Inevitavelmente, cada manifestação da indústria cultural reproduz as pessoas tais como as modelou a indústria em seu todo".

A dominação econômica e cultural, que se impõe à massa de trabalhadores na sociedade de classes, não somente dificulta que as pessoas submetidas aos padrões de alta produção e consumo enxerguem a dinâmica desfavorável dessa estrutura monopolista, como minimizam as suas chances de refletirem sobre ela e, por consequência, de revoltarem-se.

Adorno e Horkheimer (1985, p. 109) são categóricos ao dizerem que o "mecanismo da oferta e da procura continua atuante na superestrutura como mecanismo de controle em favor dos dominantes". Críticos ao sistema, os autores da Escola de Frankfurt destacam que "os consumidores são os trabalhadores e os empregados", e que "a produção capitalista os mantém tão bem presos em corpo e alma que eles sucumbem sem resistência ao que lhes é oferecido", caindo na ideia fabricada do "mito do sucesso" e servindo insistentemente aos desejos da "ideologia que os escraviza".

Mesmo sendo elaboradas e difundidas no contexto dos anos 1940, as concepções dos teóricos alemães construíram um extenso e profundo pensamento acadêmico em torno dos processos e efeitos culturais e sociais que se manifestam até hoje nos inúmeros estudos.

Teixeira Coelho (2006, p. 23), nesse sentido, entende que a cultura de massa continua alienando o 
indivíduo, que é conduzido e induzido a "não formar uma imagem de si mesmo diante da sociedade". Para o autor, ao visar principalmente à diversão, "a indústria cultural estaria mascarando realidades intoleráveis e fornecendo ocasiões de fuga da realidade", com o único objetivo de comercializar seus produtos.

Ao se comparar a dinâmica da indústria cultural com os efeitos da produção midiática na cobertura esportiva sobre o público, é pertinente considerar que o processo de alienação alcança, também, os jovens aspirantes a jogadores de futebol no Brasil, que buscam no esporte a riqueza e a fama, a despeito do fracasso econômico da maioria esmagadora dos jogadores profissionais brasileiros.

Tal busca pelo sucesso no esporte representa não apenas o sonho dos adolescentes de brilharem nos gramados e na televisão, mas também uma forma de transformar o panorama socioeconômico da família, geralmente de origem humilde financeiramente. Além do mais, vale ressaltar que a mídia seleciona as pautas tão somente conforme sua estratégia de atrair audiência e lucro, privilegiando a espetacularização, os assuntos inusitados capazes de chamar a atenção do público por meio da diversão e do prazer passional.

Nessa perspectiva, como pontuam Bianco e Rodrigues (2012, p. 265), "pouco se discute sobre processos de venda de passes de jogadores, negócios associados ao evento esportivo e sua gestão pelos dirigentes e federações". Há de se considerar, ainda, a seletividade na cobertura futebolística, na qual as notícias e debates são pautados apenas nos clubes e jogadores de destaque no cenário nacional e internacional, promovendo a impressão de que tais expoentes representam o mercado profissional do futebol como um todo.

A espetacularização do futebol, portanto, se traduz na difusão de imagens nas quais jogadores oriundos de famílias pobres alcançam o estrelato. Essas imagens são frequentes e repletas de elementos espetaculares que chamam a atenção. As transmissões dos torneios europeus são bons exemplos, tendo como atrações os estádios suntuosos, sobre os quais atuam os jogadores em momento de glória na carreira, que concedem diversas entrevistas e estrelam anúncios publicitários dos produtos da moda.

Esse tipo de conteúdo ganha ainda mais apelo junto aos jovens ao passo que necessidades normativas são criadas no imaginário coletivo pela imprensa, estabelecendo alguns padrões de consumo como condições essenciais para ser reconhecido e conquistar prestígio social. Na sociedade em que tudo se resume a coisas e a consumo de coisas, a própria relação entre os homens é marcada pela posse de coisas. A mercadoria, segundo Marx (2006, p. 94-95), sendo fruto do trabalho de produção, adquire um caráter de troca que media a relação social dos produtores, determinada pelo valor dos produtos do trabalho. Logo, o pensador alemão fala em uma relação social entre pessoas transformada em relação material e em relação social entre coisas.

\section{A SOCIEDADE DO ESPETÁCULO E OS PADRÕES DE CONSUMO}

O filósofo Guy Debord (2005) compreende que, desde a modernidade - período que marcou a ascensão burguesa e uma nova configuração nas relações de poder econômico -, as sociedades dos países ocidentais encontram-se na era do espetáculo, cujas imagens são essencialmente mediadoras das relações entre os homens. Segundo o autor, porém, o espetáculo não funciona simplesmente com base em um conjunto de imagens, mas sim em uma mediação realizada pelas imagens nas dinâmicas sociais.

$\mathrm{Na}$ visão do pensador francês, o espetáculo constitui-se na figura da própria sociedade e como parte da sociedade. Como parte, portanto, reúne em si todo olhar e toda consciência, estabelecendo padrões, normas e tendências à coletividade, mormente com relação ao consumo de mercadorias. Dessa forma, o espetáculo é resultado dos modos de produção que marcaram o período moderno e, tanto o seu desenvolvimento quanto o seu fim, têm como consequência a si próprio, uma espécie de "automovimento" aparente de afirmação econômica.

Para Debord (2005, p. 9), o espetáculo promove a inversão da realidade em uma representação ilusória, é "o coração da irrealidade da sociedade real". De acordo com o autor, sob "todas as suas formas particulares, informação ou propaganda, publicidade ou consumo direto de divertimentos, o espetáculo constitui o modelo da vida socialmente dominante".

O conceito de Sociedade do Espetáculo, apresentado pelo filósofo francês em meados dos anos 1960 como a afirmação da aparência no lugar do real, ajuda a compreender diversos fenômenos da vida 
humana na contemporaneidade. Sendo exposto com uma enorme positividade aos indivíduos, o espetáculo "nada mais diz senão o que é bom aparece e o que aparece é bom" (DEBORD, 2005, p. 12).

Logo, no contexto das sociedades de massa, os reais valores do espetáculo estão na aparência e não fundamentalmente na vivência de experiências e na posse de bens materiais. Ou seja, não basta adquirir uma mercadoria ou um serviço e desfrutar de seus valores de uso, faz-se necessário que esse valor se estenda de modo abstrato ao indivíduo e de alguma forma se incorpore à sua imagem social. O autor explica:

A primeira fase da dominação da economia sobre a vida social levou, na definição de toda a realização humana, a uma evidente degradação do ser em ter. A fase presente da ocupação total da vida social pelos resultados acumulados da economia conduz a um deslizar generalizado do ter em parecer, que todo o "ter" efetivo deve tirar o seu prestígio imediato e a sua função última. Ao mesmo tempo, toda a realidade individual se tornou social, diretamente dependente do poderio social, por ele moldada. Somente nisto em que ela não é, lhe é permitido aparecer (DEBORD, 2005, p. 13).

Enquanto modelo dominante nas sociedades contemporâneas, o espetáculo impõe ao indivíduo a necessidade de aparecer, ainda que para isso precise assumir sacrifícios e exceder todos os limites imagináveis. Uma pessoa pode, por exemplo, comprar o carro do ano, parcelar o pagamento em dezenas de prestações, ultrapassar seu orçamento e, por consequência, ter dificuldades para se sustentar nas necessidades mais básicas e essenciais, como alimentação, moradia e vestimenta. Socialmente, porém, será notada e reconhecida como bem-sucedida em virtude da imagem e do valor do carro que dirige, simplesmente por uma questão de aparência e prestígio, e não de realidade.

Nessa perspectiva aberta por Debord (2005) para a compreensão da sociedade, a mídia ocupa posição central como difusora de crenças e valores supremos a serem perseguidos com afinco pelos indivíduos - no caso específico, os valores da imagem e do espetáculo.

Com base nessas concepções, Kellner (2004, p. 5) entende que espetáculos são tipos de fenômenos que, na esfera da cultura da mídia, "representam valores básicos da sociedade contemporânea" e "determinam o comportamento dos indivíduos e dramatizam suas controvérsias e lutas [...]".

Segundo o teórico, a espetacularização da vida presente nos produtos da indústria cultural tem como um dos principais efeitos a construção de sonhos e desejos. Para o autor, além de abordar importantes aspectos da vida comum de modo acessível e atraente, a cultura da mídia proporciona "material ainda mais farto para as fantasias e sonhos, modelando o pensamento, o comportamento e as identidades".

Kellner (2004) explica que toda a economia global gira em torno do espetáculo. A competitividade entre as empresas envolve uma guerra das marcas, que buscam a todo instante oferecer diversão aos seus públicos potenciais, com vistas a associar suas imagens aos produtos do entretenimento midiático nos comerciais de TV, games, filmes ou em eventos esportivos, como é o caso do futebol.

O espetáculo midiático tem como estratégia o culto à celebridade que, segundo Kellner (2004, p. 7), "proporciona os principais padrões e ícones da moda, do visual e da personalidade. No mundo do espetáculo, a celebridade representa cada segmento social relevante", a exemplo da política, entretenimento, esportes, negócios, entre outros.

Para compreender essas proposições, basta pensar em Cristiano Ronaldo e Neymar Jr., dois jogadores de futebol com destaque global. Ambos, como astros da bola e garotos-propaganda de diversas marcas, são capazes de influenciar milhares de comportamentos sociais e de consumo por meio de suas imagens icônicas.

No início de 2010, por exemplo, o ainda garoto Neymar, então atleta do Santos Futebol Clube, apareceu nos jogos e entrevistas com um novo corte de cabelo, o "moicano". Na época, foi notável a extensa quantidade de jovens e adultos que desfilavam nas ruas com o mesmo visual adotado pelo craque brasileiro. Isso demonstra que, muito além de futebolistas estrelados, Cristiano (CR7) e Neymar (NRJ) se transformaram em marcas milionárias e influentes.

Em discussão relacionada à Psicologia Social, Aronson, Wilson e Akert (2015, s/n) explicam que o comportamento individual é fortemente influenciado por normas sociais vigentes nos ambientes em que os indivíduos estão inseridos. Qualquer grupo social 
funciona segundo normas, e cada pessoa pertencente ao grupo tem um papel social a cumprir. "Enquanto as normas especificam como os membros devem agir, os papeis especificam como as pessoas que ocupam certas posições no grupo devem se comportar".

Em sociedades complexas, como as inseridas nos grandes centros urbanos, cabe à mídia o papel de elaborar e disseminar as normas sociais a serem assimiladas pelos cidadãos. Operando sob o viés da indústria cultural, a mídia (junto com o mercado publicitário) estabelece o consumo massificado como norma social, determinando os papeis sociais a serem assumidos para que os indivíduos sejam reconhecidos, aceitos e prestigiados no círculo social.

Zygmunt Bauman (2008) descreve que, nesse contexto, para conquistar a subjetividade e a identidade, o indivíduo se vê na dupla condição de consumidor e mercadoria. Os membros da sociedade do consumo são obrigados a assumirem o consumo como vocação e adotarem características de mercadoria para serem aceitos socialmente e terem direito à subjetividade.

$\mathrm{Na}$ sociedade do consumo, desde crianças e adolescentes a adultos e idosos, a despeito de gênero ou classe social, todos são conduzidos a serem, ao mesmo tempo, consumidores e mercadorias, como explica o sociólogo polonês:

[...] Bombardeados de todos os lados por sugestões de que precisam se equipar com um ou outro produto fornecido pelas lojas se quiserem ter a capacidade de alcançar e manter a posição social que desejam, desempenhar suas obrigações sociais e proteger a autoestima - assim como serem vistos e reconhecidos por fazerem tudo isso -, consumidores de ambos os sexos, todas as idades e posições sociais irão sentir-se inadequados, deficientes e abaixo do padrão a não ser que respondam com prontidão a esses apelos (BAUMAN, 2008, p. 74).

Nesse sentido, considerando a era das redes sociais da internet, Bauman (2008, p. 21) compreende que o desejo e o sonho de fama significam nada menos que ser destacado por veículos da imprensa, aparecer em milhões de telas e, assim como as celebridades, "ser visto, notado, comentado e, portanto, presumivelmente, desejado por muitos". Para o autor, a necessidade de aparecer nas mídias como produto notável e desejável ultrapassa a consciência, a ponto de ignorar o fato de que a condição duradoura de fama é sempre acessível a um minúsculo e restrito contingente de indivíduos.
É possível que essa dinâmica alcance os jovens que desejam ser jogadores de futebol famosos, incentivados a depositar suas esperanças no sucesso e, com isso, se tornarem capazes de enfrentar qualquer situação para alcançar tal posição. Sob esse ponto de vista, não basta jogar bola por amor e paixão, enquanto uma prática ou manifestação cultural e de lazer. Uma vez considerado como meio de vida, conforme teoriza Farnandéz (1974), o futebol passa a ser um meio para alcançar a ascensão social, ao passo que imagens de ídolos futebolísticos que atingiram o ápice da glória e da popularidade servem como referência para os jovens aspirantes a jogadores profissionais.

O futebol, que poderia ser utilizado como instrumento de políticas públicas de esporte voltadas para promover integração social, saúde, educação, cultura e cidadania, resume-se hoje à condição de produto de espetáculo e de fonte de ilusão, visto que o sucesso na profissão está reservado a uma parcela ínfima de atletas.

\section{EM BUSCA DO SONHO: ENTREVISTA EM GRUPO COM JOGADORES DE BASE}

A entrevista no formato de grupo focal com jovens atletas aspirantes ao mercado profissional do esporte teve como objetivo compreender as suas motivações em buscarem no futebol uma carreira de sucesso, e a influência da mídia nesse processo. O Grupo Focal (GF) consiste numa técnica qualitativa de coleta de dados cuja principal proposta é "perceber os aspectos valorativos e normativos que são referência de um grupo em particular" (COSTA, 2005, p. 181). Por meio desta ferramenta de pesquisa, pretendeu-se identificar e entender tendências do grupo quanto ao sonho no futebol e aos potenciais motivos para a busca de tal realização.

Na prática, a entrevista foi realizada em 2017 com 11 atletas com idade entre 15 e 18 anos, vinculados às divisões de base de um clube profissional da região metropolitana de São Paulo. O time de futebol, no momento da pesquisa, trabalhava com as categorias Sub-12, Sub-14, Sub-16, Sub-19 e profissional; disputava torneios estaduais e alojava no Estádio Municipal 30 jogadores a partir de 16 anos, oriundos de cidades e estados distantes. 
Figura 1 - Entrevista com jogadores de base ${ }^{3}$

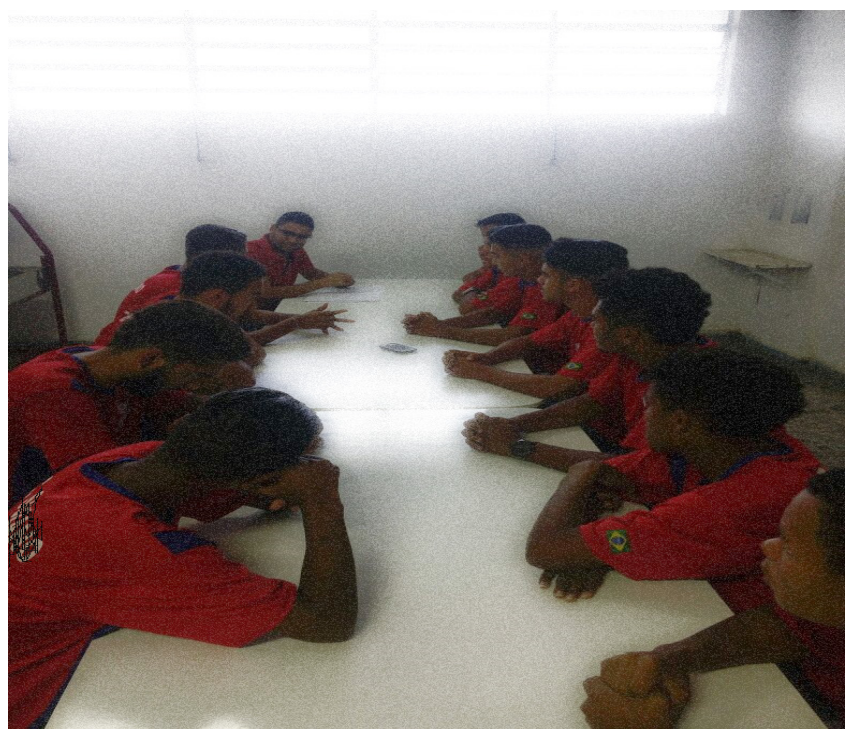

Fonte: arquivo pessoal do autor

Pelas dificuldades financeiras e a limitada estrutura do clube, nenhum jogador, da base ao profissional, recebia remuneração para atuar. Sem patrocínio oficial, a entidade conseguia arcar apenas com os custos relacionados a inscrições nos campeonatos, alimentação dos atletas que moravam no alojamento, transporte para os jogos, entre outros compromissos desportivos.

Segundo o gerente de futebol da agremiação ${ }^{4}$, o alojamento e os campos de treino e jogo eram disponibilizados pela Prefeitura do município, como uma forma de parceria e incentivo ao esporte. $\mathrm{O}$ profissional informou, também, que todos os garotos alojados e com idade escolar estavam regularmente matriculados na escola. A matrícula escolar, inclusive, é requisito indispensável para que um jogador participe das competições de base organizadas pela Federação Paulista de Futebol.

Do grupo que participou da entrevista, dois atletas estavam com 15 anos, três com 16, dois com 17 e quatro com 18. Dos 11, três eram da cidade de Jaguapitã-PR, um de Tocantinópolis-TO, dois de Carolina-MA, dois de Araguaína-TO, um de Jardim Olinda-PR, um de Ilhéus-BA e um de São Felix do Xingu-PA. Os garotos demonstraram-se bastante animados e dispostos a participar da reunião, feita no refeitório do estádio, com duração de uma hora e dez minutos, coordenada por um moderador munido de um roteiro com 15 perguntas semiestruturadas e divididas em quatro temas centrais de discussão.

No primeiro tema, o objetivo foi entender as motivações dos jovens para buscar a carreira profissional no futebol, enquanto no segundo pretendeu-se verificar quais programas midiáticos sobre esporte os jogadores de base consomem e quais são suas opiniões sobre eles. Já no terceiro, a proposta consistiu em saber se a família apoia ou não o sonho dos adolescentes, e se apoia, como é demonstrado tal incentivo. No quarto tema, por fim, buscou-se investigar se os garotos são conscientes da realidade do futebol profissional brasileiro; quais as dificuldades que enfrentam para realizar o sonho e se eles possuem outros planos caso não consigam seguir na carreira futebolística.

A interpretação e análise dos dados obtidos no GF foram feitas com base na transcrição completa da entrevista, a partir das respostas dos participantes e das observações anotadas pelo pesquisador durante o diálogo. Seguindo o método proposto por Costa (2005) para a análise dos dados, o material foi organizado em categorias relacionadas às questões e hipóteses abordadas pela pesquisa, destacando alguns depoimentos que mais enriquecem e ilustram o delineamento do estudo. Por motivos éticos, os nomes dos atletas e do clube são confidenciais, sendo identificados apenas as letras iniciais de seus nomes.

Tema 1 - motivações para ser jogador de futebol: A escolha de aventurar-se na tentativa de ser jogador profissional de futebol, de acordo com os depoimentos dos garotos, tem relação com o sonho de brilhar nos gramados e com o desejo de ajudar a família financeiramente. No olhar de cada jovem, é visível o brilho de esperança de conseguir o sucesso tão esperado e voltar para casa, um dia, com boas notícias de conquistas e realizações.

Ainda em formação como homens e atletas, jogando nas categorias de base de um clube que não oferece remuneração e tampouco boa estrutura, os adolescentes saíram de suas cidades, do cuidado dos familiares, e foram para São Paulo porque acreditam que esse Estado possibilita maiores e melhores oportunidades no mercado do futebol.

${ }^{3}$ Imagem editada de modo a não revelar a identidade dos participantes.

${ }^{4}$ Em conversa informal com o pesquisador, resguardada sua identidade. 
Quadro 1 - Respostas

S.H: Aqui no Brasil a maioria dos moleque quer ser jogador de futebol, certo?! Eu escolhi porque é o meu sonho ser jogador e dar um futuro melhor pra minha familia e pra quem vem, que no caso sãos os meus filhos. Então é isso, poder dar sempre o melhor pra minha família e fazer o que eu mais amo, que é jogar futebol.

Je.M: Ah, então, comecei desde pequeno também, né, desde criança, por causa que meu pai tem me dado apoio desde pequeno e eu vim pra São Paulo, porque eu acho que o espelho do futebol é maior, entendeu... Lá pro meu estado não é muito forte o futebol, aí eu vim pra São Paulo buscar meus objetivos e poder sair daqui vitorioso, ajudar minha família, os amigos da infância, é isso aí...

L.J: É um sonho desde criança, desde moleque, e além de ser um sonho, é algo que pode mudar a vida de todos os meus parentes, todos os meus amigos e... São Paulo, eu escolhi São Paulo porque aqui é uma vitrine, porque aqui podemos ser vistos não apenas pelo Brasil, mas pelo mundo todo ${ }^{5}$.

O fato de conviverem juntos diariamente e de terem objetivos e histórias semelhantes pode ter sido determinante para que os adolescentes emitissem respostas consideravelmente parecidas no decorrer da entrevista. Foi o que ocorreu quando se abordou a questão sobre o que, para eles, mais chamava a atenção no futebol. Na visão dos jovens atletas, a dificuldade de chegar à categoria profissional de um time expressivo é o aspecto mais chamativo no esporte, tendo em vista que conseguir espaço nos clubes da elite do futebol nacional representa uma condição altamente concorrida e complicada.

No entanto, percebe-se nos depoimentos que essa mesma dificuldade, cuja consequência reflete-se na realidade de poucos atletas conseguirem sucesso como mostra os dados da CBF (2016) e salienta Benini (2012), é também um fator motivacional para eles, que estão dispostos a enfrentar qualquer empecilho para conquistar o sonho. Fazer parte do grupo seleto de jogadores famosos representa a sensação única de mostrar aos familiares e amigos que o tamanho esforço foi recompensado.

\footnotetext{
${ }^{5}$ Optou-se por registrar a fala literal dos entrevistados, mantendo a estrutura discursiva e os erros gramaticais.
}

Além disso, tal conquista passa pela motivação de se tornar uma referência de vitória e de ser reconhecido socialmente, afora a satisfação de ser assistido pela televisão por entes queridos, amigos e conhecidos. Bauman (2008) entende que um dos grandes sonhos dos indivíduos da sociedade de consumo, na condição de consumidores e mercadorias, é ser visto e admirado por centenas de outras pessoas pelas telas de mídia.

\section{Quadro 2 - Respostas}

R.S: O que me chama atenção é as dificuldades que a gente tem no futebol. A dificuldade que... é muito difícil. São poucos que conseguem e eu quero alcançar cada dificuldade, assim.

L.J: No futebol o que me chama a atenção é... assim, o Brasil por ser um país... país do futebol, tem vários moleques querendo ser jogadores de futebol, e isso dá... tipo motivação para ser um daqueles que, se eu ser um daqueles que venceu no futebol. Mostrar para o Brasil, para o mundo que eu consegui ser jogador de futebol.

Moderador: O que você entende por vencer no futebol? O que pra você é vencer no futebol?

L.J: Vencer... vencer é chegar a ser profissional, jogando futebol profissionalmente por um time grande e disputar os maiores campeonatos do Brasil e do mundo.

M.M: O que me motiva no futebol é a tendência de muitos jogadores tentarem e poucos conseguirem. E eu quero ser uma dessas pessoas que vai conseguir e vai ajudar minha família.

T.S: O que mais me motiva é a dificuldade, porque tipo, como ele falou, cidade pequena é muito difícil, muita pessoa fica almejando a sua derrota lá: vai pra São Paulo, vai voltar. Então, eu quero ser um daqueles que tem... que pode falar futuramente: ah, eu consegui vencer todas aquelas dificuldades e hoje eu estou aqui dando um futuro melhor para minha família, para os meus amigos que me ajudaram lá atrás.

C.A: Ah, o que mais me chama atenção assim é... minha família me motiva, sabe... Porque eles passam necessidade e é o que me motiva a ser um jogador de futebol, a conquistar mesmo. E... é isso. O que me motiva é a família, que eu gosto do futebol é jogar mesmo, ser campeão de vários títulos, é isso... 
Moderador: Você falou de necessidade. Que tipo de necessidade?

C.A: Ah, ver minha família passando fome, precisando de casa assim, sem ser alugada, é isso.

Infelizmente, a realidade exposta por esta última resposta representa a de muitos outros e expõe as mazelas de um país profundamente desigual, com dificuldades de garantir às famílias de baixa renda $o$ mínimo de dignidade, como o acesso à alimentação e moradia de qualidade. Segundo dados da Oxfam Brasil ${ }^{6}$, o país é um dos mais desiguais do mundo, ao ponto de seis brasileiros concentrarem a mesma riqueza que a metade mais pobre da população, que corresponde a mais de 100 milhões de pessoas. Para ter uma ideia, 5\% dos mais ricos recebem mensalmente o mesmo valor que $95 \%$ da população trabalhadora junta.

Para os jovens que gostam de futebol e que se encontram nessas condições, o sucesso por meio da prática esportiva torna-se quase que uma obsessão, uma forma unívoca de tirar a si próprio e os familiares desse contexto. A revelação do jovem atleta sobre a situação que sua família enfrenta demonstra que o sonho dos garotos ultrapassa o individualismo e alcança dimensões coletivas. Ao serem questionados a respeito do que esperam alcançar como jogadores, os atletas expressaram o desejo de "vencer" na vida para promover ações e projetos sociais, com a finalidade de beneficiar outros meninos que, assim como eles, sonham em ser jogadores, mas que não dispõem de condições e oportunidades para tal realização.

No que se refere ao futebol, especificamente, os depoimentos indicaram que os adolescentes esperam conquistar títulos por times "grandes" no Brasil, atuar em equipes europeias e seleção brasileira.

${ }^{6}$ Informações disponíveis no site da confederação internacional: https://www. oxfam.org.br/os-numeros-das-desigualdades-no-brasil.

\section{Quadro 3 - Respostas}

M.M: Meu sonho é ser profissional, atingir um dos auge, que nenhum dos jogadores da minha cidade conseguiu. Ser uma revelação dentro da minha cidade, é conseguir ajudar minha família, tirar a dificuldade de... de... acontecer algo e poder ter um dinheiro pra estabelecer lá. Então eu quero mudar isso, não quero ficar correndo atrás em só esse sonho de ser jogador de futebol enquanto me proporcionou a... a conseguir ajudar...

L.J: Sendo um profissional do futebol, primeiramente eu gostaria de proporcionar uma qualidade de vida melhor pra minha família e ajudar também aqueles que futuramente é... é... sonharem em ser alguém como eu que sonhei, um jogador profissional de futebol, e proporcionar a eles uma facilidade maior de alcançar os seus sonhos e também ajudar a famílias deles.

Moderador: Que facilidades seriam essas?

L.J: Realizar projetos em cidades do interior, fora do Brasil também, interior do Pará, aquelas regiões do nordeste também, que ali também tem muitos jogadores que perdem, que não alcançam o futebol por não terem oportunidades.

S.H: Bom, eu espero, como todo mundo disse né, ser um grande jogador, não só ser um grande jogador, quero estar sempre entre os melhores, entendeu. Já que eu não vou falar algo repetitivo que é ajudar a família, porque isso é óbvio, todo mundo quer. Então, vou falar de títulos. Cara, eu quero sempre ser o melhor, entendeu. Se eu vou, não sei, mas é o que eu quero. Quero sempre ser o melhor, quero trabalhar sempre pra ser o melhor. $E$ ganhar as maiores coisas, como um Brasileiro, uma Libertadores, Champions League e, se Deus quiser, uma Copa do Mundo.

Je.M: É... então, como eles falaram, um atleta profissional que no futuro possa ser campeão da Copa do Mundo, onde é o meu sonho desde pequeno. E sobre minha cidade também eu gostaria que, onde eu jogava na escolinha, eu espero levantar mais lá. Lá agora no momento não tá muito no nível alto. $E$ ajudar as pessoas carentes, isso eu já falei pro meu pai quando eu saí de casa, falei que ia voltar pra ajudar minha escolinha que comecei e ajudar as pessoas carentes, que minha cidade tem muito, pessoas carentes. É isso aí, ajudar minha cidade bastante.

Os jovens atletas também buscam inspiram em jogadores de sucesso para seguir em frente no 
sonho de ser futebolista. Perguntados sobre quais futebolistas eles tinham como inspiração e por que, os adolescentes citaram nomes o de Neymar, Cristiano Ronaldo, Messi, Guerrero, Philippe Coutinho, Andrés Iniesta, Casemiro e Daniel Alves. Até Ronaldo, o "Fenômeno", que se aposentou já há algum tempo, foi mencionado. Todos eles com grande apelo midiático.

Desses jogadores, apenas Guerrero atua no futebol brasileiro. Messi e Cristiano Ronaldo, por exemplo, de modo alternado, conquistam todos os anos o título de melhor jogador do mundo. $\mathrm{O}$ catalão Iniesta brilhou por anos com a camisa do Barcelona, da Espanha. Casemiro e Marcelo defendem o Real Madri, um dos clubes mais ricos e vencedores da história do futebol. Ambos, juntamente com Neymar, Daniel Alves e Philippe Coutinho, fizeram parte do time titular da seleção brasileira na Copa do Mundo de 2018, disputada na Rússia.

Tema 2 - recepção de conteúdos midiáticos: $\mathrm{Na}$ televisão, os programas mais assistidos pelos jovens entrevistados são o Jogo Aberto, da TV Band, e o Globo Esporte, da TV Globo, transmitidos diariamente no horário de almoço. Como os jogadores almoçam juntos, seguindo o cronograma estabelecido pelo clube, provavelmente aproveitam para acompanhar as notícias e discussões sobre o que tem acontecido no mundo da bola. Os adolescentes disseram que costumam buscar informação em outros veículos televisivos também, como os canais fechados e segmentados ESPN, SporTV e Esporte Interativo.

$\mathrm{Na}$ internet, os atletas contam que acompanham futebol em sites especializados de veículos de imprensa e nas redes sociais dos atletas, como Facebook, Instagram, Youtube, com acesso feito principalmente pelo celular. Dessa forma, eles ficam sabendo do dia a dia dos jogadores, que fazem postagens acerca da rotina de treinos e até mesmo sobre a vida pessoal. A maior parte dos jovens, inclusive, revelaram consumir assuntos relacionados ao futebol com mais frequência pela internet do que pela TV.

Quanto aos programas televisivos, os atletas acham importante assisti-los para se manterem bem informados e se divertirem. Sobre o Jogo Aberto, por exemplo, eles opinaram que as "resenhas" (que significam "bate-papo" no mundo do futebol) entre o ex-jogador e comentarista Denilson "Show" e a apresentadora Renata Fan promovem entretenimento e despertam risos nas pessoas. Os garotos também observam com atenção os lances selecionados e transmitidos pelos programas, pois, segundo eles, são lances que podem ocorrer com eles futuramente.

No que se refere à pergunta sobre em qual programa de televisão os jovens gostariam de participar e ser visto enquanto jogadores, as respostas foram quase unânimes: Jogo Aberto. As justificativas diziam respeito ao fato de o programa ser um dos melhores e por passar diversão, principalmente em razão da participação do Denilson. Segundo os relatos, o ambiente do programa é descontraído, transmite alegria e permite que o jogador fique à vontade para falar de sua história. Outro aspecto destacado pelos adolescentes é que o programa abre espaço para abordar a trajetória do jogador, as dificuldades que passou até chegar ao profissional

O Globo Esporte foi mencionado em duas respostas e os argumentos são parecidos com os relacionados ao Jogo Aberto. Ser convidado para participar de um programa de TV e ter a oportunidade de contar a história (ou de ter a mesma contada) é realmente um forte desejo dos garotos. Eles afirmam que essas histórias suscitam inspiração, condição que eles também buscam: ser uma referência para outros, ou seja, ser reconhecidos e admirados.

\section{Quadro 4 - Respostas}

\section{C.A: Ah, Jogo Aberto também porque é um} programa muito famoso assim, e é bom porque você vai ser exposto para o Brasil, todo mundo vai assistir você. Pela resenha também do Denilson, te deixa mais à vontade, te deixa mais em casa, você não fica com medo de errar.

Jo.M: Ah, Jogo Aberto, né. Todo jogador almeja tá resenhando com o Denilson, resenha boa. Também falam da vida do jogador, né, que muitos possa ver, muitas pessoas assistem, e é isso...

Moderador: Fala mais um pouco sobre essa história do jogador aí. Por que que... quais são as abordagens que eles trazem sobre a história do jogador, por que que você gosta dessas histórias?

Jo.M: A dificuldade. Porque a dificuldade é grande. $E$ lá eles conseguem perguntas, o Denilson como foi um jogador, ele sabe também a vida de um jogador, como ele passa. 
L.J: Jogo Aberto também, é um programa que contém a resenha e a alegria do futebol brasileiro. $E$ eu acho que é um programa que o jogador se sente à vontade pra falar da vida... como ele conseguiu chegar como jogador profissional. Isso nos traz inspiração.

D.A: Eu vou pelo Globo Esporte também porque traz muitas notícias do clube porque também apresenta no programa o jogador, a dificuldade que eles passaram pra chegar em seus sonhos e... é isso.

Por meio dos depoimentos sobre os programas, é possível avaliar também como ocorre a recepção dos conteúdos do jornalismo esportivo por parte dos adolescentes, no que se refere à preferência pela linguagem descontraída e pertencente ao ambiente do futebol. De fato, a proximidade entre jornalismo e entretenimento na cobertura futebolística é muito forte e, efetivamente, implica a estratégia de conquistar os olhares da massa de admiradores do esporte, que não somente quer se manter bem informada, como também tem a intenção de se divertir (BARBEIRO e RANGEL, 2006; BIANCO e RODRIGUES, 2012; COELHO, 2006).

Tema 3 - apoio familiar para a realização do sonho: Com base nas respostas, constata-se que os familiares dos adolescentes não somente apoiam como apostam alto no sonho de vê-los chegarem à categoria profissional. As palavras de incentivo, bem como a contribuição financeira e orações religiosas foram as principais expressões de apoio familiar mencionadas pelos jovens. Apenas um jogador disse que há membros de sua família que não apoiam nem acreditam em seu sonho.

O apoio e consentimento familiar é primordial para os garotos buscarem seus sonhos, pois, sem isso, seria muito complicado viajarem para jogar tão longe de casa, mesmo com o clube arcando com os custos de moradia e alimentação. Um dos depoimentos revela que a família, além de incentivar, cobra por resultados em relação aos estudos. Outro ponto importante foi a posição dos pais como os maiores incentivadores dos filhos na busca pelo estrelato no futebol. Um dos atletas conta que o pai também tentou ser jogador profissional quando mais jovem, mas não conseguiu.

\section{Quadro 5 - Respostas}

T.S: Ah, minha familia me ajuda bastante, me apoiando, me dando força todos os dias, falando que eu vou conseguir, mesmo eu estando aqui bem longe deles, estando com saudade deles. $A$ gente só se vê em férias, em julho e dezembro. E o meu pai me ajuda bastante (...ilegível...), de já ter tentado ser jogador e por falta de apoio, antigamente ele não conseguiu. Ele entende como que é isso. Aí ele me ajuda bastante dando apoio, conversando comigo todas as noites, mandando mensagem e... é isso.

\section{L.J: Meus familiares me apoiam não só}

financeiramente, mas também psicologicamente, pra mim não abaixar a cabeça, não desistir, não se preocupar muito como eles estão... e também, além disso, eles me alertam para que eu também estude para que no futuro se não der certo, que eu tenha pelo menos uma base de estudo boa.

Moderador: Eles te dão essa conscientização de pensar que pode não dar certo, eles trabalham isso com você?

L.J: Sim.

C.A: Ah, eles me apoiam com mensagem, falando pra mim continuar, em orações também, pra mim nunca desistir do meu sonho, sempre estar estudando também, e é isso, sempre nunca desistir do que eu quero.

Observando os depoimentos, nota-se que os familiares, e principalmente os pais dos jovens, apoiam mutuamente os garotos na tentativa de buscar a carreira futebolística. Em alguns casos, isso ocorre em função das experiências frustradas dos próprios pais no futebol, que passam a depositar em seus filhos todas as fichas para ver seus sonhos de infância realizados.

Com efeito, como se pode ver, o sonho do estrelato no futebol não pertence apenas aos adolescentes, mas também aos familiares que, assim como os próprios garotos, enxergam no esporte um caminho potencial à ascensão social e ao enriquecimento.

Tema 4 - dificuldades na categoria de base: Segundo os relatos, a maior dificuldade enfrentada pelos jovens é a saudade da família. Em todas os depoimentos, esse fator foi apresentado como um dos principais obstáculos para a conquista do objetivo. 
Perguntados se aguentariam suportar a falta dos familiares para realizarem o sonho de ser jogadores profissionais, eles responderam unanimemente que sim, com a justificativa de que tal sofrimento faz parte.

Um outro ponto abordado pelos atletas foi a necessidade de se tornarem adultos mais cedo, adiantando um processo de desenvolvimento na medida em que precisam ficar longe de casa e enfrentar sozinhos os desafios do dia a dia, ou seja, assumindo responsabilidades que a grande maioria dos adolescentes de suas idades geralmente desconhece. A partir da entrevista, é possível perceber que, além do mais, os garotos carregam o compromisso e a esperança de tentar ajudar a família financeiramente.

Quadro 6 - Respostas

C.A: A maior dificuldade é a saudade de casa, dos familiares, porque nós podia estar aí curtindo a vida namorando, nós está aqui seguindo a carreira desde cedo já, mas a maior dificuldade mesmo é a saudade de casa.

Moderador: Você está a quanto tempo já longe de casa?

C.A: Ah, faz uns dois meses, dois meses e alguma coisa, dois meses e pouquinho..

Mediador: Você acha que vai conseguir ficar mais tempo?

C.A: Sim. (...inelegível...).

L.J: A maior dificuldade eu acredito que é a saudade, porque estar a mais de dois mil quilômetros de casa não é fácil. Então, acho que a saudade é a maior dificuldade. Mas também tem, como você falou, se tornamos adultos mais cedo. Temos que ter mais compromisso, mais... é isso mesmo, mais compromisso com as nossas coisas, porque se tornar adulto mais cedo não é algo fácil.

V.H: Assim, como todo mundo vai falar de saudade, um outro fator assim que tenho bastante dificuldade, dos mais novos, é ser adulto com 16 anos, né, que é difícil pra caramba, ter muita cabeça e juízo.

Moderador: E o que você entende ser adulto com 16 anos?

V.H: Então, é difícil. Tem que ter muita responsabilidade como você pensa, como você age, essas questões assim, sabe.
S.H: Também é saudade. Mas por isso que o futebol é bom, né, até no simples treino, quando entra ali você esquece de tudo, e até da saudade não entra pro campo. Então é por isso que o futebol é a paixão, né, porque você entra ali e você esquece de tudo, tudo, tudo... Saudade, quem namora, namorada, tudo. E é por isso, cara, por isso que motiva estar firme, entende.

Sobre a realidade do futebol brasileiro, os atletas demonstraram-se plenamente conscientes das péssimas condições que a maioria esmagadora dos clubes brasileiros oferece. Majoritariamente, o grupo de entrevistados disse que a realidade do futebol é mascarada pela televisão.

As opiniões dos jovens são respaldadas em suas próprias experiências diárias, na limitada estrutura que recebem para treinar e jogar, a qual contrasta com as imagens difundidas pelos programas esportivos e transmissões. A cobertura futebolística feita pela imprensa é pautada nos grandes times do futebol brasileiro, que contam com centros de treinamento impecáveis e que, em geral, atuam em estádios e arenas de excelente estrutura e estética.

\section{Quadro 7 - Respostas}

V.H: Assim, nem tudo o que a televisão passa é a mesma coisa que você vive, entendeu. Às vezes você olha... como a gente joga... na televisão a gente olha o gramado é a coisa mais perfeita, quando você vai ver, o gramado não é a mesma coisa assim, é mais esse ponto. Nem tudo o que televisão passa é a realidade.

C.A: Ah, a televisão às vezes é muito mentirosa, sabe, porque mostra, tipo, mostra a imagem de um clube, assim, a estrutura, aí mostra aquela coisa mais linda, aí você entra no clube, ai é tudo diferente, é... tudo ruim assim as coisas, mas é isso. Às vezes ela mente muito às vezes. Ou às vezes mostra que é ruim, mas se entra ali é boa.

Moderador: Você já teve uma experiência dessa, que você viu que pela televisão era uma coisa e chegou lá era outra?

C.A: Não, não tive ainda não, mas já tem que ter essa consciência, tem que esperar sempre o ruim de algum lugar que você for. Eu vim com essa mente pra cá, que ia ser ruim, que ia ser sempre ruim... é isso. 
M.M: Digamos que não só a televisão aliena as pessoas, mas também como a internet. Muitos, não sei aqui, mas muitos antes de ir pro um clube, ele pesquisa quem é ou quem era o antigo presidente, alguma coisa assim, e muitas das vezes é antigo os padrões que a internet pegou naquele tempo, e quando você chega lá é outra coisa. E é um ponto que poderia estar atualizado, a cada (...ilegível...), a cada momento.

No fim da entrevista, questionados sobre quais profissões seguiriam caso a carreira como jogador de futebol não vingasse, os jovens atletas responderam que gostariam de prosseguir trabalhando na área do esporte. Preparador físico, treinador, professor de educação física, fisioterapeuta e nutricionista foram as posições profissionais citadas nas respostas. Essas respostas são muito importantes porque indicam que esses jovens são conscientes da possibilidade de fracasso inerente à aventura no futebol e já pensam em um segundo plano profissional.

\section{CONSIDERAÇÕES FINAIS}

A espetacularização futebolística arquitetada pela mídia é resultado de uma estratégia mercadológica que objetiva conquistar audiência e auferir lucro junto ao mercado publicitário, considerando o forte traço cultural e o apelo social que o futebol tem em relação ao povo brasileiro, além de sua capacidade de despertar paixões e atrair olhares.

Como consequência desse círculo comercial, o futebol não é o único a ser transformado em produto. Nessa perspectiva, os jogadores mais destacados, personagens do reluzente espetáculo midiáticoesportivo, tornam-se mercadorias e ícones, na medida em que apresentam potencial para serem celebridades e ídolos.

$\mathrm{Na}$ verdade, esse patamar de estrelato se conserva reservado a um número ínfimo de jogadores pertencentes a clubes de massa, com habilidade acima da média e capacidade de chamar a atenção pública. Já a maior parte dos times e atletas profissionais brasileiros ocupa um espaço à margem da cobertura jornalística e, além de trabalhar sob condições precárias e de receber salários irrisórios, fica praticamente invisível para o grande público.

Dessa forma, alguns efeitos da influência da espetacularização midiática sobre o sonho de jovens aspirantes à carreira futebolística são encontrados na entrevista em grupo. Os jogadores de base entrevistados, além de consumirem conteúdo futebolístico em programas televisivos e na internet, aspiram participar dos mesmos e vislumbrar neles suas histórias contadas. Do mesmo modo que os jovens se inspiram com o sucesso dos seus ídolos, desejam um dia ser referência para outros garotos que, como eles, sonham ser jogadores de futebol.

Ajudar a família financeiramente, promover projetos sociais, ter reconhecimento e ser um astro midiático vencedor são pilares que movem e sustentam a aspiração desses jovens, que deixam suas casas ainda muito novos para enfrentar desafios e dificuldades, com vistas a alcançar o objetivo final do sucesso.

A partir dessas reflexões e das lamentáveis notícias acerca de golpes promovidos por falsos empresários, de casos de pedofilia nas categorias de base e nas escolinhas de futebol, de infrações ao Estatuto da Criança e do Adolescente (ECA) demonstradas em pressões psicológicas por resultados expressivos e nos centros de treinamento e alojamentos com péssimas estruturas (alimentação, moradia e remuneração), é pertinente a realização de outros estudos sobre o tema que envolve as divisões de base do futebol brasileiro, explorando a hipótese de o esporte no geral ser utilizado como instrumento de políticas públicas voltadas para a promoção de socialização, bem-estar e cidadania, sobretudo aliado à educação, como ocorre em países avançados.

Espera-se, portanto, que este artigo contribua de alguma forma para que a comunidade acadêmica realize outros estudos sobre a temática, a sociedade se conscientize mais a respeito da realidade do futebol brasileiro e que o Poder Público fiscalize com mais rigor as categorias de base dos clubes profissionais, para que tragédias como o incêndio que matou dez garotos no Ninho do Urubu, centro de treinamento do Clube de Regatas do Flamengo, em 2019, sejam evitadas.

\section{REFERÊNCIAS}

ADORNO, Theodor; HORKHEIMER, Max. Dialética do Esclarecimento. 1. ed. Rio de Janeiro: Zahar, 1985.

ARONSON, Elliot; WILSON, Timothy; AKERT, Robin. Psicologia Social. 8. ed. Rio de Janeiro: LTC, 2015. Disponível em: $<$ https://integrada.minhabiblioteca.com.br/\#/ 
books/978-85-216-2946-7/cfi/6/2[;vnd.vst.idref=cover $>$. Acesso em: 3 março 2016, 21:30.

BARBEIRO, Heródoto; RANGEL, Patrícia. Manual do Jornalismo Esportivo. São Paulo: Contexto, 2006.

BAUMAN, Zygmunt. Vida para Consumo: a transformação das pessoas em mercadoria. Rio de Janeiro: Zahar, 2008.

BENINI, Paulo André Cren. O jogo da minha vida: histórias e reflexões de um atleta. São Paulo: Leya, 2012.

BIANCO, Nélia; RODRIGUES, Monique. Diferenciação na Cobertura Esportiva a partir da TV Pública Brasileira. In: MARQUES, José Carlos; MORAIS, Osvando J. de (Org.). Esportes na idade mídia-diversão, informação e educação. São Paulo: INTERCOM, 2012. p. 263-284.

COELHO, Paulo Vinícius. Jornalismo Esportivo. São Paulo: Contexto, 2006.

COELHO, Teixeira. O que é indústria cultural. 21. ed. São Paulo: Brasiliense, 2006.

CONFEDERAÇÃO BRASILEIRA DE FUTEBOL. Raio X do futebol: número de clubes e jogadores. Disponível em: $<$ http://www.cbf.com.br/noticias/a-cbf/raio-x-do-futebolnumero-de-clubes-e-jogadores\#.WZ9Qe7Zv_IV>. Acesso em: 24 ago. 2017.

CONFEDERAÇÃO BRASILEIRA DE FUTEBOL. Raio X do futebol: salário dos jogadores. Disponível em: $<$ http:// cbf.com.br/notícias/a-cbf/raio-x-do-futebol-salario-dosjogadores\#.Vs8IMtlR_IU>. Acesso em: 25 fev. 2016.

COSTA, Maria Eugênia Belczak. Grupo Focal. In: DUARTE, Jorge; BARROS, Antônio (Org.). Métodos e Técnicas de Pesquisa em Comunicação. $2^{\circ}$ ed. São Paulo: Atlas, 2005. p. $180-187$.

DEBORD, Guy. A sociedade do espetáculo. Lisboa: Edições Antipáticas, 2005.

FERNÁNDEZ, Maria do Carmo Leite de Oliveira. Futebol - fenômeno linguístico: análise linguística da imprensa esportiva. 1. ed. Rio de Janeiro: Pontifícia Universidade Católica e Editora Documentário, 1974.

GASTALDO, Édison. "O país do futebol” mediatizado: mídia e Copa do Mundo no Brasil. Sociologias, Porto Alegre, ano 11, n. 22, jul/dez. 2009, p. 352-369.

GASTALDO, Édison; HELAL, Ronaldo. Homo Ludens e o futebol-espetáculo. Revista Colombiana de Sociologia, v. 36, n. 1, jun. 2013, p. 111-122.

HUIZINGA, Johan. Homo Ludens: o jogo como elemento da cultura. São Paulo: Perspectiva, 2005.

KELLNER, Douglas. A Cultura da Mídia e o Triunfo do Espetáculo. Líbero. Ano VI, vol. 6, n. 11, 2004.

MAGALHÃES, Lívia Gonçalves. Histórias do Futebol. São Paulo: Arquivo Público do Estado, 2010.
MARCONDES FILHO, Ciro. O capital da notícia: jornalismo como produção social da segunda natureza. 2. ed. São Paulo: Ática, 1989.

MARX, Karl. O capital: crítica da economia política. 23. ed. Rio de Janeiro: Civilização Brasileira, 2006.

PENA, Felipe. Teoria do Jornalismo. 2. ed. São Paulo: Contexto, 2008.

PRONI, Marcelo Weishaupt. Esporte espetáculo e futebolempresa. 1998. 262f. Tese (doutorado) - Universidade Estadual de Campinas, Faculdade de Educação Fisica, Campinas, SP. Disponível em: <http://www.repositorio. unicamp.br/handle/REPOSIP/275330>. Acesso em: 4 abr. 2017.

RIAL, Carmen. Rodar: a circulação dos jogadores de futebol brasileiros no exterior. Horiz. Antropol, vol. 14, n. 30, Porto Alegre, jul/dez. 2008. Disponível em: http://dx.doi. org/10.1590/S0104-71832008000200002. Acesso em: 6 mai. 2017.

RIBEIRO JÚNIOR, Amaury et al. O lado sujo do futebol: a trama de propinas, negociatas e traições que abalou o esporte mais popular do mundo. 1. ed. São Paulo: Planeta, 2014.

SODRÉ, Muniz. O monopólio da fala: função e linguagem da televisão no Brasil. Petrópolis: Vozes, 1984.

SOMOGGI, Amir. Finanças dos clubes brasileiros em 2016. Disponível em: <https://pt.slideshare.net/ AmirSomoggi?utm_campaign=profiletracking\&utm medium $=$ sssite\&utm_source $=$ ssslideview $>$. Acesso em: $2 \overline{7}$ ago. 2017.

WITTER, José Sebastião. Breve história do futebol brasileiro. São Paulo: FDT, 1996.

\section{AGRADECIMENTOS}

Agradecemos aos professores e mestres Elizeu do Nascimento Silva e Hércules Moreira, e ao jornalista Thiago Caetano, pelas importantes contribuições para a elaboração e realização deste estudo. 